\title{
Short Communication / Nota Científica An amendment to the original description for Pitcairnia ulei (Pitcairnioideae - Bromeliaceae)
}

\author{
Camila Correia de Araujo ${ }^{1,3}$ \& Maria das Graças Lapa Wanderley ${ }^{2}$
}

\begin{abstract}
This study provided an amendment to the original description for Pitcairnia ulei (Pitcairnioideae - Bromeliaceae). Key words: Cerrado, Pepinia, Poales, winged seeds.

Resumo

Este estudo forneceu uma emenda à descrição original de Pitcairnia ulei (Pitcairnioideae - Bromeliaceae).

Palavras-chave: Cerrado, Pepinia, Poales, sementes aladas.
\end{abstract}

Pitcairnia L'Her. is traditionally recognized in two subgenera distinguished by seed morphological characters: Pitcairnia subgenus Pitcairnia presents bicaudate ovules and seeds, whereas Pitcairnia subgenus Pepinia (Brongn. ex André) Baker is characterized by winged ovules and seeds, sometimes without appendages (Smith $\&$ Downs 1974). The reliability of this infrageneric circumscription was discussed by André (1870), Baker (1881), Smith \& Downs (1974), Varadarajan \& Gilmartin (1988a, b), Grant \& Zijlstra (1998), and Taylor \& Robinson (1999). Based on seeds morphology analysis by Scanning Electron Microscopy (SEM) and leaf anatomy, Taylor \& Robinson (1999) pointed a high variability of the seeds due to ecological and geographic conditions. In a recent phylogenetic study based on macro and micromorphology analysis of the genus Pitcairnia, Saraiva et al. (2015) found that the two subgenera do not emerge as monophyletic, not agreeing with the infrageneric actual classification. The phylogenetic tree pointed Pitcairnia bradei Markgr., Pitcairnia cristalinensis (Leme) D.C.
Taylor \& H. Rob., and Pitcairnia ulei L.B. Sm. as a clade; these species present canaliculate and coriaceous leaves, yellow flowers and winged seeds, besides rheophytic habit.

For Pitcairnia ulei, Smith \& Downs (1974) described only obtuse and short-caudate ovules, the fruit was not observed (as well as in the original description - there is no fruit in the holotype) and this species was allocated in Pitcairnia subg. Pitcairnia. In addition to its known restricted distribution (Brazil - Goiás state and Distrito Federal), current collections of this species were made in watercourse banks (rheophytic habit), with plants in fruit, exhibiting winged seeds, and in accordance to the infrageneric concept these characteristics belong to the species allocated in Pitcairnia subgenus Pepinia.

This note provides an amendment to Pitcairnia ulei description, adding features of fruit and seeds (form, color and measures) and illustration, besides contributing to the future morphological and phylogenetic studies about Pitcairnia s.l.

\footnotetext{
Instituto de Botânica, Prog. Pós-graduação em Biodiversidade Vegetal e Meio Ambiente, Av. Miguel Estefno 3687, Água Funda, 04301-902, C.P. 68041, São Paulo, SP, Brazil.

${ }^{2}$ Instituto de Botânica, Núcleo de Pesquisa Curadoria do Herbário, Av. Miguel Estefno 3687, Água Funda, 04301-902, C.P. 68041, São Paulo, SP, Brazil.

${ }^{3}$ Author for correspondence: camilaaraujo18@gmail.com
} 
Pitcairnia ulei L.B. Smith, Bol. Mus. Nac. Rio de Janeiro 15: 5, plate I, figs. h-j. 1952. emend. C.C. Araujo \& Wand. Type: BRAZIL. Goiás: region of Corumbá de Goiás, Ule 788 (holotype [mounted in two sheets with same herbarium number, 46458] $\mathrm{R}$ ! barcode 000046458; isotype [fragment] US! barcode 00088950).

Figs. 1;2

Rheophyte, caespitose; stem covered by leaf sheaths. Leaves tristichously-spiral, isomorphic, linear, long-attenuate, subcanaliculate; sheath castaneous, 3-5.5 $\times 4-7 \mathrm{~cm}$, deltoid, laxly inserted in stem; blade green, $84-93 \times 1.2-1.5 \mathrm{~cm}$, glabrous in adaxial face and lepidote in abaxial face; margin entire. Peduncle green to orange, $45.5-61.1 \mathrm{~cm}$ long, glabrescent; bracts green-yellow, 3.8-67 cm long, lepidote, the basal foliaceous, surpassing the internodes, the apical triangular-lanceolate, smaller than the internodes, apex attenuate. Inflorescence simple or compound, suberect; rachis $41-64.5 \mathrm{~cm}$ long, erect, glabrescent; primary bracts $3-4.5 \mathrm{~cm}$ long. Floral bracts green to orange, $0.6-1.2 \mathrm{~cm}$ long, lanceolate. Flowers $4.5-6.5 \mathrm{~cm}$ long, slightly zygomorphic at anthesis; pedicels orange to green, 0.8-1.6 cm long; sepals orange, 1.9-2.2 cm long, free, lanceolate, acute apex, lepidote; petals yellow, 4.8-5.7 cm long, free, oval-lanceolate; apex rounded, overlapping at anthesis (partial zygomorphy); petal appendages ca. $0.5 \mathrm{~cm}$ long, adnate, apex free and dentate; stamens $4.4-5.1 \mathrm{~cm}$ long, free, filaments yellow, anthers yellow, $0.8-1 \mathrm{~cm}$ long, basifixed; ovary $0.9-1 \mathrm{~cm}$ long, semi-inferior, entering more than its half in the receptacle, style yellow, ca. 5 $\mathrm{cm}$ long, stigma yellow, ca. $0.2 \mathrm{~cm}$ long, spiralconduplicate. Fruit green, $1.4-1.8 \mathrm{~cm}$ long, globose, lepidote; seeds $0.1-0.2 \mathrm{~cm}$ long, winged, falciform to reniform, numerous.

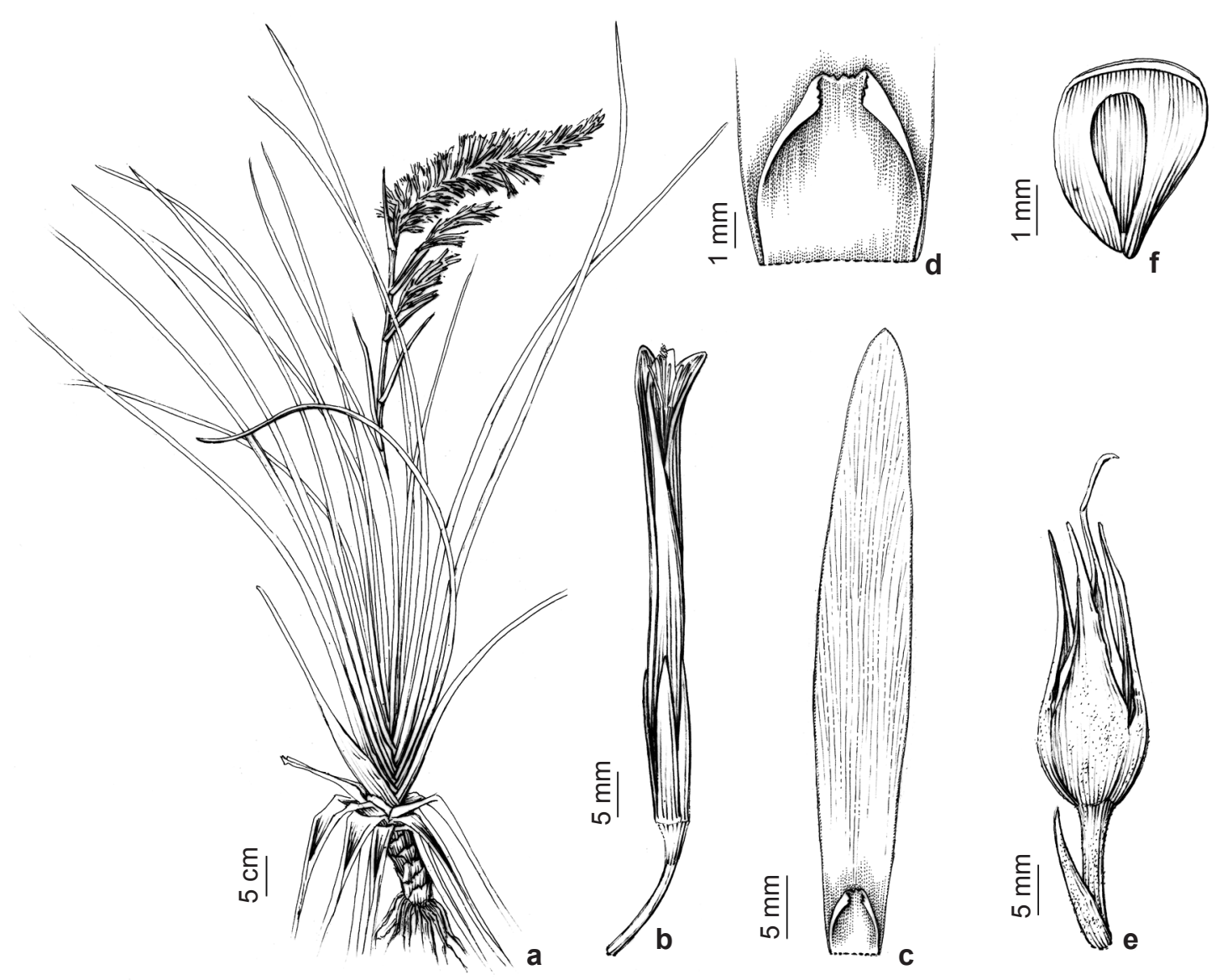

Figure 1 - a-f. Pitcairnia ulei - a. habit; b. flower; c. petal and petal appendage; d. petal appendage; e. fruit; f. seed. (a-e. C.C. Araujo 15; f. C.C. Araujo 51). Illustration: Klei Sousa. 

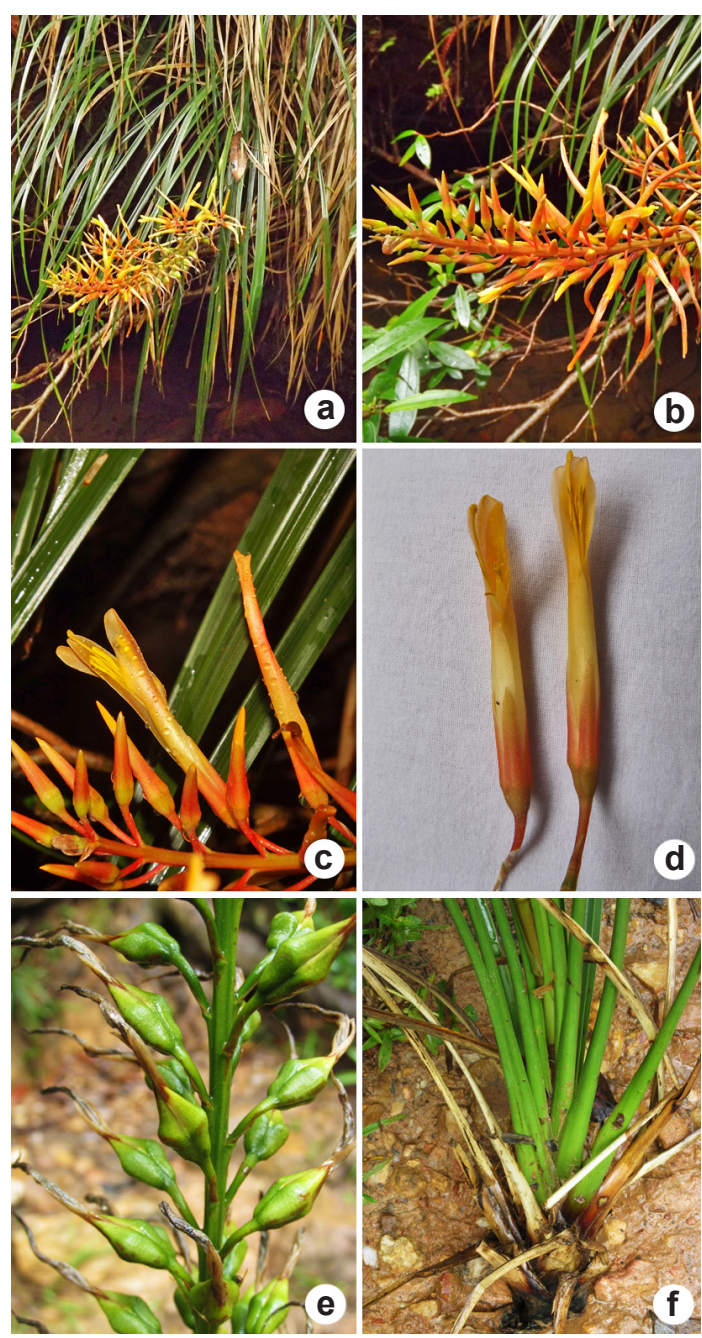

Figure 2 - a-f. Pitcairnia ulei - a. habit; b-d. flowers; e. fruits; f. leaves tristichously-spiral. (a-d. C.C. Araujo 15; e-f. C.C. Araujo 51). Photos: C.C. Araujo.

Distribution and habitat: Brazil, in Goiás state, and in the Distrito Federal. In Distrito Federal is found in waterways margins, mainly in forest phytophysiognomies. Flowering in February, and
July to November, fruiting in February, October and November.

Specimens examined: BRAZIL. DISTRITO FEDERAL: Brasília, VIII.1964, Irwin \& T.R. Soderstrom 5782 (SP); VII.1982, B.A.S. Pereira 326 (IBGE); IX.1982, J.H. Kirkbride Jr. 4870 (UB); VI.1985, R.C. Mendonça \& M. Ribeiro 480 (IBGE, SP); II.1999, C. Proença et al. 2088 (UB); 1557'40"S, 4756'36"W, XI.2011, D.P. Saraiva et al. 309 (CEN); 15'34'55"'S, 4802'49"'W, IX.2012, J.E.Q. Faria 2820 (UB); 15 58'37'S, 47052'10"'W, VII.2012, M. Aparecida-da-Silva et al. 7730 (IBGE). Gama, Córrego Gama, IX.1965, Irwin et al. 8681 (NY, UB, US); XI.1965, Irwin et al. 10137 (NY!, US). Cidade Satélite Brazlândia, $15^{\circ} 34^{\prime} 54.3^{\prime \prime}$ S, 48 02 '50.3”'W, XI.2014, C.C. Araujo 51 (SP). Cidade Satélite Lago Sul (Brasília), 1557’40.4”S, 4756’39.2”W, X.2013, C.C. Araujo 15 (SP). Cidade Satélite São Sebastião, 1557'14.2”'S, 4740'21.3”'W, XI.2014, C.C. Araujo \& S.E. Martins 50 (SP). GOIÁS: Alto Paraíso de Goiás, $14^{\circ} 11^{\prime} 38^{\prime \prime} \mathrm{S}, 47^{\circ} 50^{\prime} 27^{\prime \prime} \mathrm{W}$, XI.2011, D.P. Saraiva et al. 293 (CEN).

Smith (1952) cited only one specimen as type, which is deposited in $\mathrm{R}$ mounted in two sheets. However there is a duplicate deposited in US, therefore an isotype, composed only of parts of the flower.

Pitcairnia ulei as well as Pitcairnia cristalinensis and Pitcairnia bradei is endemic to Brazilian Cerrado. Characters that differ among these species are presented in detail in Table 1.

Pitcairnia cristalinensis occurs in Goiás state and is very similar to $P$. ulei. This species was before synonymized under $P$. ulei (Forzza et al. 2014 apud Saraiva et al. 2015) but today is an accepted name according to Flora do Brasil (2020).

Pitcairnia bradei is endemic to the Minas Gerais state (Flora do Brasil 2020) and differs from $P$. ulei mainly by fragrant flowers. Smith \& Downs (1974) cited two records of $P$. bradei, both from the same location, at Distrito Federal - Irwin et al. 8681 (Córrego Gama, IX.1965, UB!, NY!, US) and Irwin et al. 10137 (Gama, XI.1965, NY!, US). However we have seen these vouchers and determined as $P$. ulei.

Table 1 - Taxonomic characters that differ among the species Pitcairnia ulei, Pitcairnia bradei, and Pitcairnia cristalinensis, which were observed in this study. *Information for Pitcairnia bradei and P. cristalinensis were based on Flora do Brasil (2020) and Leme (1995), respectively.

\begin{tabular}{llll}
\hline Species & Inflorescence & Floral bracts & Petal appendage \\
\hline Pitcairnia ulei & Simple or compound & Smaller than pedicels & Present \\
Pitcairnia bradei & Simple* & Smaller than pedicels* & Absent* \\
Pitcairnia cristalinensis & Simple* & Equaling to exceeding ovary* & Present* \\
\hline
\end{tabular}




\section{References}

André E (1870) Pepinia aphelandraeflora. L'Illustration Horticole 17: 32-33.

Baker JG (1881) A synopsis of the genus Pitcairnia. Journal of Botany, British and Foreign 19: 225 233.

Flora do Brasil 2020 [under construction] Jardim Botânico do Rio de Janeiro. Available at $<$ http:// floradobrasil.jbrj.gov.br/>. Access on 18 April 2017.

Grant JR \& Zijlstra G (1998) An annotated catalogue of the generic names of the Bromeliaceae. Selbyana 19: 91-121.

Leme EM (1995) Miscellaneous new species of Brazilian Bromeliaceae. Selbyana 16: 110-122.

Saraiva DP, Mantovani A \& Forzza RC (2015) Insights into the evolution of Pitcairnia (Pitcairnioideae-
Bromeliaceae), based on morphological evidence. Systematic Botany 40: 726-736.

Smith LB (1952) Boletim do Museu Nacional de Rio de Janeiro - Botanica II 15: 5, t. 1, f. h,i,j.

Smith LB \& Downs RJ (1974) Flora Neotropica. Monograph n. 14. (Pitcairnioideae, Bromeliaceae). Hafner Press, New York. 658p.

Taylor DC \& Robinson H (1999) A rejection of Pepinia (Bromeliaceae: Pitcairnioideae) and taxonomic revisions. Harvard Papers in Botany 4: 203-217.

Varadarajan GS \& Gilmartin AJ (1988a) Taxonomic realignments within the subfamily Pitcairnioideae (Bromeliaceae). Systematic Botany 13: 294-299.

Varadarajan GS \& Gilmartin AJ (1988b) Seed morphology of the subfamily Pitcairnioideae (Bromeliaceae) and its systematic implications. American Journal of Botany 75: 808-818. 